\title{
RADIOCARBON DISTRIBUTION IN NORTHWEST BELARUS NEAR THE IGNALINA NUCLEAR POWER PLANT
}

\author{
Nikolaj D Mikhajlov • Vladimir M Kolkovsky • Iren D Pavlova \\ Institute of Geological Sciences of the National Academy of Sciences of Belarus, Kuprevich Street 7, Minsk, \\ 220141 Republic of Belarus
}

\begin{abstract}
Since 1994, the Institute of Geological Sciences has undertaken an environmental monitoring program to measure radiocarbon levels in territory adjacent to active nuclear power plants (NPP). We determined ${ }^{14} \mathrm{C}$ concentrations in natural objects from areas contiguous to Ignalina NPP as well as ${ }^{14} \mathrm{C}$ background concentration in areas remote from the NPP. In the environs of the Ignalina station comparatively elevated levels of ${ }^{14} \mathrm{C}$ were observed in vegetation and waters of Lake Drisvyaty. This appears to be a consequence of release of carbon radioisotope into the atmosphere and probably into waters of the lake during operation of the nuclear reactor.
\end{abstract}

\section{INTRODUCTION}

The accident at the Chernobyl Nuclear Power Plant (NPP) in the Ukraine raised questions in Belarus concerning the reliability of operational cycles of the NPPs surrounding the territory of our country. Some answers can be obtained by studying the distribution of radiocarbon as one of the components of environmental radiocontamination. For this purpose we chose as an object of research the area in northwestern Belarus where the Ignalina NPP (INPP), in Lithuania $\left(55^{\circ} 37^{\prime} \mathrm{N}, 26^{\circ} 36^{\prime} \mathrm{E}\right)$, is situated most closely to Belarus. The INPP, located on Lake Drisvyaty (Fig. 1), is equipped with Chernobyltype reactors; 2 units operate there.

${ }^{14} \mathrm{C}$ can be formed in the active zone of nuclear reactors of any type, where flows of neutrons can interact with reactor components, coolant, the nuclear fuel moderator or impurities contained in these. The rate of ${ }^{14} \mathrm{C}$ formation in the fuel depends mainly on concentrations of nitrogen admixtures. What distinguishes the INPP reactor, which uses boiling water under pressure as a coolant (heat-carrier) and graphite as a moderator, is the presence of abundant nitrogen in an active zone used in a mixture with helium for cooling and a large mass of carbon in the moderator. This results in a significant rate of ${ }^{14} \mathrm{C}$ generation, approximately an order of magnitude greater than in reactors of other types (Ryblevsky et al. 1979). ${ }^{14} \mathrm{C}$ formed in the coolant and moderator is released partially or completely into the environment as a gas-aerosol complex, and also from reactor fuel in the form of radioactive waste.

\section{METHODS}

${ }^{14} \mathrm{C}$ concentrations were measured at some experimental sites selected on the basis of their location with respect to the nuclear plant. The INPP premises are characterized in general by increased technogenic load on the landscape and by destruction of the soil/vegetation cover. Two canals designed for water intake for cooling the reactor and for dumping coolant into a reservoir extend from the NPP to Lake Drisvyaty, and a thermal anomaly has been recorded within the lake (Novikov et al. 1994).

A water-controlled area of Lake Naroch, a hydrological post in Belovezhskaya Pushcha, and some sites in the Dokshitsy District of the Vitebsk Region (Berezinsky Reserve) and the Gorki and Dubrovno Districts of the Mogilev Region were chosen as control regions, presumably not exposed to the NPP influence (Table 1).

Measurement of ${ }^{14} \mathrm{C}$ activity was performed at the Institute of Geological Sciences using liquid scintillation counting (LSC). Benzene synthesis from samples of vegetation, surface water, and mollusk 


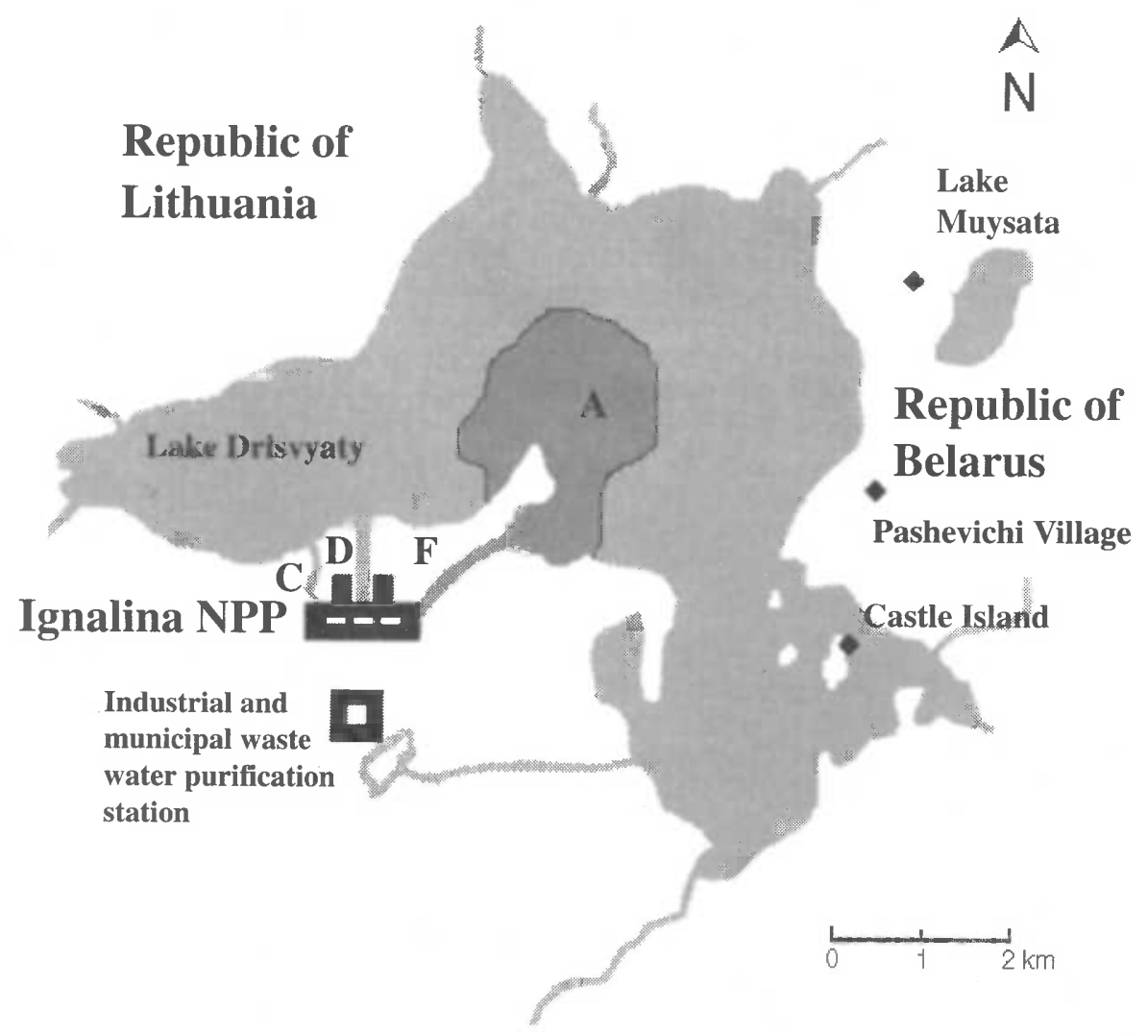

Figure 1 Environs of Ignalina NPP and sample sites. $\mathbf{A}=$ heat anomaly of the lake; $\mathbf{C}=$ INPP industrial and rainwater sewer; $\mathbf{D}=$ INPP water intake canal; $\mathbf{F}=$ INPP heated water outflow canal; $\$=$ sample selection sites.

shells was performed using a synthesis installation (Skripkin and Kovaliukh 1994; Skripkin and Kovaliukh 1998) that enables production of highly purified benzene in sufficient amounts for counting. $\beta$-counting was done using a Tri-Carb ${ }^{\circledR}$ TR-2500 AB and an LKB 1211 Rackbeta. The results of ${ }^{14} \mathrm{C}$ activity are expressed as a percentage of the modern standard.

\section{RESULTS}

As shown by the results of ${ }^{14} \mathrm{C}$ measurement (Table 2), the region of Belarus contiguous with the INPP is distinguished by an increase in ${ }^{14} \mathrm{C}$ concentrations in vegetation of up to $120 \%-150 \%$ relative to the present level in undisturbed areas. Bulrush sampled near Castle Island in Lake Drisvyaty and 2-yr-old pine cones growing on the lakeside close to Pashevichi Village exhibit the maximum ${ }^{14} \mathrm{C}$ accumulation. Relatively high ${ }^{14} \mathrm{C}$ values were observed directly in water from Lake Drisvyaty, connected by canals with the INPP.

At the same time, water from the closed Lake Muysata does not manifest the NPP influence in every year observed. ${ }^{14} \mathrm{C}$ concentrations vary from the current level $(102 \mathrm{pMC})$ up to a comparatively increased one (132 pMC). Similar ${ }^{14} \mathrm{C}$ contents $(120-150 \mathrm{pMC})$ are also observed in carbonate of mollusk shells (Anadonta, Unio, and Dreisena) collected along lake shores. ${ }^{14} \mathrm{C}$ release from INPP 
Table 1 Radiocarbon concentration in natural objects from Belarus, far from any NPP

\begin{tabular}{llclr}
\hline Sample type & Collection site & $\begin{array}{r}\text { Year } \\
\text { dated }\end{array}$ & Lab code & $\begin{array}{r}{ }^{14} \text { C content } \\
(\mathrm{pMC})\end{array}$ \\
\hline Cowberry leaves & Brest region & 1994 & IGSB-76 & 102 \\
Moss & Brest region & 1994 & IGSB-77 & 107 \\
Oak leaves & Brest region & 1996 & IGSB-255 & 104 \\
Oak leaves & Gorki region & 1994 & IGSB-54 & 101 \\
Annual grasses & Gorki region & 1994 & IGSB-41 & 98 \\
Carbonate from water & Vitebsk region, & 1994 & IGSB-385 & 128 \\
& Medsozol Lake & & & \\
Birch leaves & Vitebsk region, & 1994 & IGSB-26 & 115 \\
& Medsozol Lake & & & \\
Atmospheric carbonate & Minsk & 1994 & IGSB-9 & 94 \\
Moss & Minsk region & 1994 & IGSB-15 & 126 \\
Pine needles & Mogilev region & 1994 & IGSB-56 & 86 \\
Birch leaves & Mogilev region & 1994 & IGSB-57 & 92 \\
Atmospheric carbonate & Naroch lake & 1994 & IGSB-80 & 103 \\
Moss & Naroch lake & 1996 & IGSB-257 & 99 \\
Annual rings of pine (1984) & Vitebsk region & 1987 & IGSB-6 & 105 \\
Annual rings of pine (1985) & Vitebsk region & 1987 & IGSB-7 & 105 \\
Annual rings of pine (1986) & Vitebsk region & 1987 & IGSB-8 & 102 \\
Carbonate of mollusk shells & Vitebsk region, & 1997 & IGSB-413 & 127 \\
(Anadonta, Unio, and Dreisena) & Losvido Lake & & & \\
\hline
\end{tabular}

operation was revealed as well in eggshell carbonate from hens whose food consisted of cereals grown near the NPP (Pashevichi Village, 152 pMC).

The analysis of ${ }^{14} \mathrm{C}$ in annual rings of trees (Fig. 2) shows the tendency of ${ }^{14} \mathrm{C}$ distribution during the period 1979-1994 and is closely comparable to determinations of ${ }^{14} \mathrm{C}$ concentrations in water from Lake Drisvyaty made by Banis (1988), who found that they varied from 115 to $150 \mathrm{pMC}$ during 1978-1986.

In comparison with 1994 values, our 1996 measurements showed a reduction in ${ }^{14} \mathrm{C}$ concentrations in plants. This phenomenon seems to be associated with the fact that in 1996 the Ignalina NPP was repeatedly subjected to preventive maintenance.

\section{CONCLUSION}

Our determinations of ${ }^{14} \mathrm{C}$ concentration in the atmosphere, surface waters, and vegetation are essentially the first ones for the Belarus area. They characterize both ${ }^{14} \mathrm{C}$ background concentrations (without penetration of technogenic radioisotopes) and ${ }^{14} \mathrm{C}$ values in the region adjoining the Ignalina NPP. Obvious variations in the distribution of ${ }^{14} \mathrm{C}$ concentrations are associated with penetration into surrounding air and surface water of "surplus" ${ }^{14} \mathrm{C}$ from the nuclear power plant operating in its standard regime. The data obtained point to the value of including ${ }^{14} \mathrm{C}$ measurement in a radioisotope monitoring system. 
Table 2 Radiocarbon concentrations in natural objects from areas contiguous to Ignalina NPP

\begin{tabular}{|c|c|c|c|c|}
\hline Sample type & Collection site & $\begin{array}{l}\text { Year } \\
\text { dated }\end{array}$ & Lab code & $\begin{array}{l}{ }^{14} \mathrm{C} \text { content } \\
(\mathrm{pMC})\end{array}$ \\
\hline Atmospheric carbonate & Lake Drisvyaty & 1994 & IGSB-65 & 96 \\
\hline Atmospheric carbonate & Lake Drisvyaty & 1995 & IGSB-175 & 110 \\
\hline Atmospheric carbonate & Lake Drisvyaty & 1996 & IGSB-380 & 106 \\
\hline Carbonate from water & Lake Drisvyaty & 1994 & IGSB-384 & 144 \\
\hline Carbonate from water & Lake Muysata & 1995 & IGSB-382 & 132 \\
\hline Carbonate from water & Lake Drisvyaty & 1996 & IGSB-383 & 154 \\
\hline Algaes & Lake Drisvyaty & 1994 & IGSB-39 & 105 \\
\hline Algaes & Lake Drisvyaty & 1995 & IGSB-179 & 111 \\
\hline Barley & Shore of Lake Drisvyaty & 1996 & IGSB-210 & 117 \\
\hline Bulrush & Lake Drisvyaty, Castle Island & 1994 & IGSB-22 & 150 \\
\hline Bulrush & Lake Drisvyaty, Castle Island & 1995 & IGSB-176 & 143 \\
\hline Bulrush & Lake Drisvyaty, Castle Island & 1996 & IGSB-191 & 119 \\
\hline Flax & Shore of Lake Muysata & 1996 & IGSB-206 & 104 \\
\hline Oats & Shore of Lake Volosovo & 1996 & IGSB-192 & 111 \\
\hline Alder leaves & Lake Drisvyaty, Castle Island & 1994 & IGSB-38 & 107 \\
\hline Alder leaves & Lake Drisvyaty, Castle Island & 1995 & IGSB-174 & 117 \\
\hline Alder leaves & Lake Drisvyaty Castle Island & 1996 & IGSB-199 & 115 \\
\hline Alder leaves & Shore of Lake Drisvyaty & 1994 & IGSB-42 & 112 \\
\hline Alder leaves & Shore of Lake Drisvyaty & 1995 & IGSB-172 & 110 \\
\hline Young pine cone & Shore of Lake Drisvyaty & 1995 & IGSB-182 & 119 \\
\hline Young pine cone & Shore of Lake Drisvyaty & 1996 & IGSB-215 & 115 \\
\hline 2-yr-old pine cones & Shore of Lake Drisvyaty & 1994 & IGSB-31 & 190 \\
\hline 2-yr-old pine cones & Shore of Lake Drisvyaty & 1995 & IGSB-167 & 138 \\
\hline 2-yr-old pine cones & Shore of Lake Drisvyaty & 1996 & IGSB-214 & 118 \\
\hline $\begin{array}{l}\text { Carbonate from mollusk shells } \\
\text { - Anadonta Unio }\end{array}$ & Lake Muysata & 1996 & IGSB-314 & 133 \\
\hline $\begin{array}{l}\text { Carbonate from mollusk shells } \\
\text { - Anadonta Unio }\end{array}$ & Lake Muysata & 1996 & IGSB-315 & 135 \\
\hline $\begin{array}{l}\text { Carbonate from mollusk shells } \\
\text { - Dreisena }\end{array}$ & Lake Drisvyaty & 1996 & IGSB-313 & 124 \\
\hline $\begin{array}{l}\text { Mollusk soft tissue - } \\
\text { Anadonta Unio }\end{array}$ & Lake Muysata & 1996 & IGSB-280 & 123 \\
\hline $\begin{array}{l}\text { Soft tissue of mollusk - } \\
\text { Dreisena }\end{array}$ & Lake Drisvyaty & 1996 & IGSB-281 & 124 \\
\hline Eggshell from household hens & $\begin{array}{l}\text { Stankevichi Village (Lake } \\
\text { Muysata) }\end{array}$ & 1997 & IGSB-393 & 137 \\
\hline Eggshell from household hens & Pashevichi Village & 1997 & IGSB-394 & 152 \\
\hline
\end{tabular}




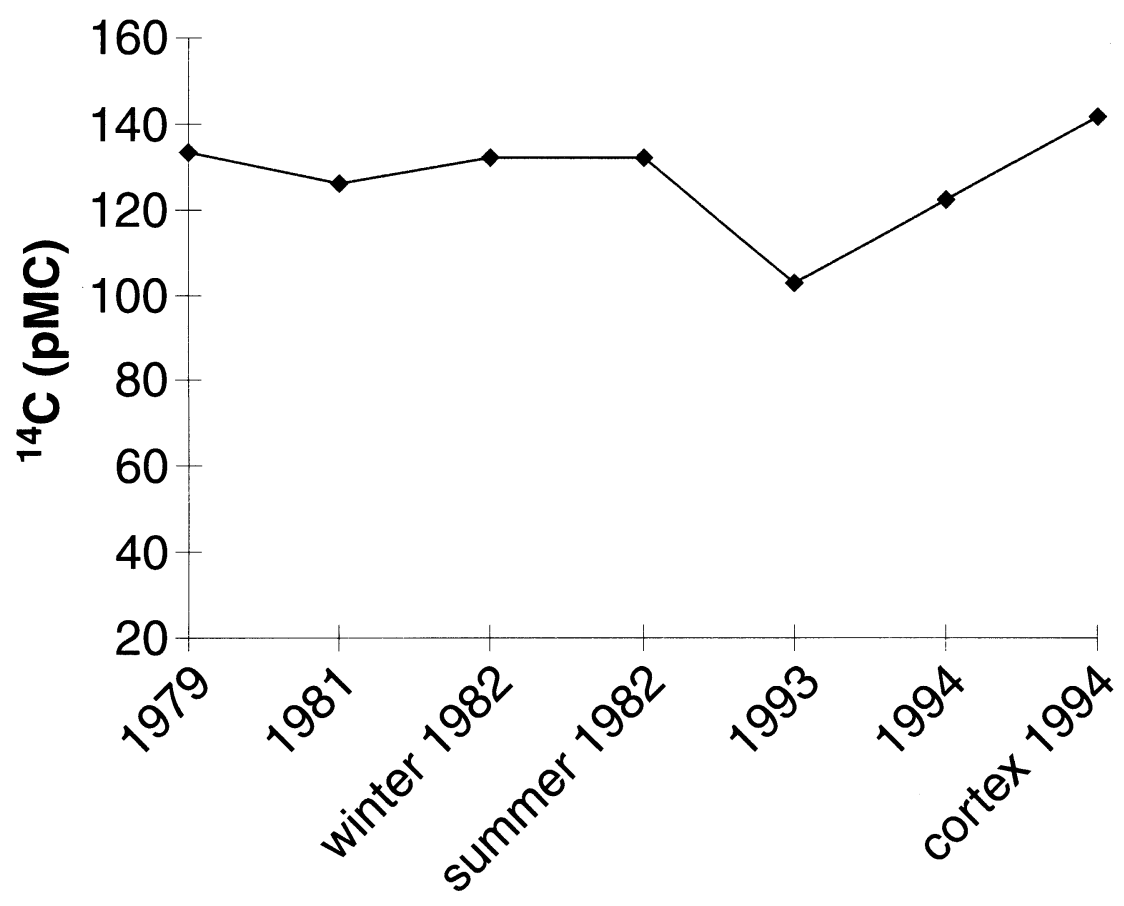

\section{Annual pine rings}

Figure $2{ }^{14} \mathrm{C}$ concentrations in annual rings of pine growing along the Lake Drisvyaty shoreline

\section{REFERENCES}

Banys J. 1988. Isotope hydrogeochemical investigation in the region of Ignalina APS. Isotope Geochemical Research in Baltic Countries and Belarus (Tallinn): 515 (in Russian).

Novikov G, Romanov V, Kapelchikov N. 1994. Influence of Ignalina NPP on conditions of Drisvyaty Lake. Byelorussian State University Bulletin, Series 2: Chemical, Biological, and Geographical Sciences 1: 63-6 (in Russian).

Ryblevsky V, Golenetsky S, Kirdin G. 1979. Radioactive carbon in the biosphere. Moscow: AtomIzdat. $196 \mathrm{p}$ (in Russian).
Skripkin V, Kovaliukh N. 1994. A universal technology for oxidation of carbon-containing materials for radiocarbon dating. Conference of Geochronology and Dendrochronology of Ancient Towns and Radiocarbon Dating of Archeological Finds. 1994 Oct 31-Nov 4; Vilnius, Lithuania. Abstracts and Papers. Vilnius: Vilnius University Press. p 37-42.

Skripkin V, Kovaliukh N. 1998. Recent developments in the procedures used at the SSCER laboratory for the routine preparation of lithium carbide. Radiocarbon 40(1):211-4. 